\title{
The Law Enforcement of Rehabilitation Sanctions Against Narcotics Users
}

\author{
Irsano Marthanova Erisky*) and Widayati**) \\ *) Central Java High Court, E-mail: irsano.alvino@gmail.com \\ **) Universitas Islam Sultan Agung (UNISSULA) Semarang
}

\begin{abstract}
The purpose of this study is to identify and analyze the enforcement of rehabilitation sanctions against narcotics users at the Central Java Regional Police and to identify and analyze the obstacles in law enforcement of rehabilitation sanctions against narcotics users at the Central Java Regional Police. This study uses a sociological juridical approach, with descriptive analytical research specifications. The data used are primary and secondary data which will be analyzed qualitatively. The research problems were analyzed using the theory of justice and the theory of expediency. The results of the study conclude that looking at the criminal provisions of Article 127 paragraphs (2) and (3), it can be concluded that judges in deciding cases referred to in Article 127 paragraph (1) are required to pay attention to the articles that regulate rehabilitation provisions so that later addicts and victims Drug abusers can be rehabilitated. The obstacles that come from the government, it is stated that there are 5 (five) obstacles, namely: a) There has not been a special place for addicts and victims of narcotics abusers to rehabilitate, $b$ ) The problem of rehabilitation costs for convicts of abuse cases narcotics, c) There is no rehabilitation center appointed by the Government, d) There is a difference in information between the defendant, witnesses and the results of the criminalistic laboratory. e) An execution problem occurred.

Keywords: Law Enforcement; Rehabilitation; Narcotics.
\end{abstract}

\section{Introduction}

Crime can be interpreted criminologically and juridically. Crime in the sense of criminology is a human act that tarnishes the basic norms of society. This is intended as the actions of individuals who violate the rules that live and thrive in society. Juridical crime, i.e. an evil act or evil act in the sense of criminal law means that the crime is formulated in criminal regulations. ${ }^{1}$ For modern countries, the desire to effectively guarantee the rights of citizens and regulate the orderly state administration has encouraged every country to adopt constitutionalism, including the legal regulation regarding narcotics rehabilitation. ${ }^{2}$ The settlement of criminal cases is carried out through the evidentiary process, namely the prosecution process

\footnotetext{
${ }^{1}$ Yusril IA, Bambang Tri Bawono and Ira Alia Maerani, Criminal Investigation of Motorcycle Stealing Goods. Law Development Journal ISSN : 2747-2604 Volume 3 Issue 1, March 2021, (169 - 174). file:///C:/Users/win10e/Downloads/14866-35234-1-PB.pdf

${ }^{2}$ Adhe I smail A, Constitutionalism Concept in Implementation of Indonesian State Administration. Jurnal Daulat Hukum Volume 4 Issue 2, June 2021 ISSN: 2614-560X. http://jurnal.unissula.ac.id/index.php/RH/article/view/15737/5567.
} 
which is carried out directly in an experiment. ${ }^{3}$ In judicial practice, the process always begins with an arrest, detention, then being prosecuted by the public prosecutor, which ends with a judge's decision. ${ }^{4}$

Act No. 35 of 2009 concerning Narcotics has given different treatment to perpetrators of abuse or users of Narcotics. Narcotics users or addicts as perpetrators of narcotics crimes can be subject to sanctions in the form of imprisonment, in addition to being subject to sanctions in the form of rehabilitation.

Rehabilitation is an effort to restore and restore the condition of former NAZA abusers/dependents back to health in terms of physical, psychological, social and spiritual/religious (faith) health. With these healthy conditions, it is hoped that they will be able to return to normal functioning in their daily lives, both at home, at school/campus, at work and in their social environment. ${ }^{5}$.

Act No. 35 of 2009 concerning Narcotics contains Article 54 which regulates rehabilitation. Article 54 which reads "Narcotics addicts and victims of Narcotics abuse are obliged to undergo medical rehabilitation and social rehabilitation". Medical rehabilitation is a process of integrated treatment activities to free addicts from narcotics dependence. Medical rehabilitation for narcotics addicts can be carried out in hospitals appointed by the Minister of Health, namely hospitals organized by the government or by the community.

The police is a subsystem in the criminal justice system that is sufficient to determine the success and work of the entire system in providing services to the public. ${ }^{6}$ Law enforcement is carried out repressively by law enforcement officers, in the form of imposing sanctions by criminals, in this case carried out by the police, prosecutors, courts, and correctional institutions. Based on the analysis that narcotics crime law enforcement is carried out with penal efforts, if non-penal efforts can no longer be done. ${ }^{7}$

In addition to treatment or care through medical rehabilitation, the healing process of Narcotics addicts can be carried out by the community through religious and traditional approaches. While social rehabilitation is a process of integrated recovery activities both physically, mentally and socially so that former narcotics addicts can immediately return to carrying out social functions in carrying out community life. What is meant by former Narcotics addicts here are people who have recovered from dependence on Narcotics physically and psychologically.

\footnotetext{
${ }^{3}$ Ardito, YP, Umar Ma'ruf and Aryani Witasari. Implementation of Criminal Action Prosecution Online in Realizing Principle of Fast Prosecution, Simple \& Low Cost, Jurnal Daulat Hukum, Volume 4 Issue 2, June 2021 ISSN: 2614-560X. http://jurnal.unissula.ac.id/index.php/RH/article/view/15737/5567.

${ }^{4}$ Ferry, SW and Arpangi. Settlement Policy of Criminal Actions which Performed by Children through Penal Mediation. Jurnal Daulat Hukum Volume 4 Issue 2, June 2021 ISSN: 2614-560X. http://jurnal.unissula.ac.id/index.php/RH/article/view/15737/5567.

${ }^{5}$ Dadang Hawari, Psikiater, 2006, Penyalahgunaan \& Ketergantungan NAZA (Narkotika, Alkohol, \& Zat Adiktif), Jakarta : Gaya Baru, p.132.

${ }^{6}$ Nurfita AT, Sri Endah Wahyuningsih and Arpangi. The Police Role in Investigating the Crime of Child Murder as a Result of Infidelity Relationships. Law Development Journal ISSN : 2747-2604 Volume 3 Issue 1, March 2021, (86 - 92). http://jurnal.unissula.ac.id/index.php/ldj/article/view/14866/5481.

${ }^{7}$ Indah Lestari, Sri Endah Wahyuningsih, Penegakan Hukum Pidana Terhadap Pengguna Narkoba di Polda Jateng, Jurnal Hukum Khaira Ummah, Vol.2 No.3, September 2017.
} 
The number of narcotics abuse cases in the Central Java Regional Police jurisdiction is currently increasing. This can be seen from the number of cases that increase every year. The increasing number of consumers using Narcotics certainly invites the operation of a Narcotics syndicate network, the Directorate of Drug Investigation of the Central Java Police revealed 1,372 cases of narcotics abuse in 2017, in 2018 totaling 1,591 cases. Comparison up 16 percent, with the biggest influence of target users being at the age of students and college students, the data is certainly very concerning because the threat of loss of quality youth is increasingly real. Prevention and control efforts carried out by the Central Java Regional Police, especially the Narcotics Investigation Unit, in this case require further steps in the law enforcement process.

Law enforcement against crimes in Indonesia, especially in terms of sentencing, should refer to the approach of legal norms that are fostering criminals by providing guidance or medical and social rehabilitation. Thus, it can improve the perpetrators and users of narcotics crime abuse. This should be able to provide discourse to judges in imposing rehabilitation sanctions on Narcotics users. In empirical reality in the field of punishment in general still adheres to the concept of only imposing imprisonment, without any medical and social rehabilitation. Thus, it can provide an illustration that the crime will only stop for a moment and will reappear in the social life of the community.

Thus, there is a need for a change in the sense of reviewing Indonesian criminal law which so far is still based on the philosophical principles and foundations of foreign nations towards a criminal law system based on the values of the One Godhead as the values of national and state life which aspired to. ${ }^{8}$

The existence of the Narcotics Law and Psychotropic Law is a legal political effort by the Indonesian government to tackle narcotics and psychotropic crimes. Thus, it is hoped that the formulation of the Law can tackle illicit trafficking and abuse of Narcotics and Psychotropics, as well as become a reference and guideline for courts and the organizers or implementers of court decisions that apply the Law, especially judges in imposing criminal sanctions on crimes that occur. .

Narcotics crime as regulated in Act No. 35 of 2009 concerning Narcotics provides a fairly heavy criminal sanction. However, in reality the perpetrators of crimes are actually increasing, and for the convicts in reality it is not a deterrent and in fact there is a tendency to repeat it again. This can be caused by the existence of a criminal imposition factor that has no impact or deterrent effect on the perpetrators.

The realization of overcoming the eradication of criminal acts of narcotics abuse cannot be separated from the role of law enforcement officers, but requires cooperation from various parties, including community participation. The form of community participation here can be in the form of providing information about criminal acts of narcotics abuse to Polri investigators, as well as assisting the success

\footnotetext{
${ }^{8}$ Sri Endah Wahyuningsih, 2014, Urgensi Pembaharuan Hukum Pidana Materiel Indonesia Berdasarkan Nilai-Nilai Ketuhanan Yang Maha Esa, Jurnal Pembaharuan Hukum Volume 1 No.1, January-April 2014.
} 
of the social rehabilitation program that has been regulated by Act No. 35 of 2009 on Narcotics. ${ }^{9}$

The purpose of this study was to determine and analyze the enforcement of rehabilitation sanctions against narcotics users in the Central Java Regional Police, to identify and analyze the obstacles and solutions in law enforcement of rehabilitation sanctions against narcotics users in the Central Java Regional Police.

\section{Research Methods}

The approach method used in this study uses a sociological juridical method, namely in addition to using legal principles and principles in reviewing, viewing, and analyzing problems, as they are ${ }^{10}$ which in this case relates to law enforcement of rehabilitation sanctions against narcotics users at the Central Java Police. The specifications in this study are analytical descriptive. Descriptive research is a research method that is intended to systematically and accurately describe the facts and characteristics of the research field.

Sources of data used in this study are primary, secondary, and tertiary data sources. Primary data sources are objects that are observed directly in the field and interviewed informants. Primary legal materials consist of: Act No. 35 of 2009 on Narcotics. Tertiary legal materials consist of dictionaries, encyclopedias.

The data collection method used to obtain data that has a relationship with the object of research is interviews with resource persons and document review, while the data analysis method used is qualitative data analysis in this study including data reduction, data presentation and conclusions/verification.

\section{Results and Discussion}

\subsection{Law Enforcement of Rehabilitation Sanctions Against Narcotics Users at the Central Java Police}

Provisions regarding the rehabilitation of narcotics addicts are regulated in Act No. 22 of 1997, Circular Letter of the Supreme Court Number 07 of 2009 and Act No. 35 of 2009 and the latest is the issuance of Circular Letter of the Supreme Court Number 04 of 2010 which is a revision of Circular Letter of the Supreme Court Number 07 of 2009. Prior to the issuance of Act No. 35 of 2009, provisions regarding the rehabilitation of narcotics addicts were regulated in Articles 45 and 47 of Act No. 22 of 1997:

Article 45

"Drug addicts are required to undergo treatment and/or treatment" Article 47

(1) Judges who examine Narcotics Addict cases may:

\footnotetext{
${ }^{9}$ Interview with Kompol Wahidin, Committee for Drug Sub-Directorate 3 of the Central Java Police, on 28 June 2021 at 11.00 WIB.

${ }^{10}$ Soerjono Soekanto, 2010, Pengantar Penelitian Hukum, Universitas Indonesia Press, Jakarta, p. 10.
} 
a. Decide to order the person concerned to undergo treatment and/or treatment through rehabilitation if the Narcotics Addict is proven guilty of committing a Narcotics crime; or

b. Determine to order the person concerned to undergo treatment and/or treatment through rehabilitation if the Narcotics Addict is not proven guilty of committing a Narcotics crime

The period of undergoing treatment and/or treatment for narcotics addicts as referred to in paragraph (1) letter a, is calculated as the period of serving the sentence.

Then in the Circular Letter of the Supreme Court Number 07 of 2009 urges judges who examine cases of narcotics addicts to apply the provisions of Article 47 of Act No. 22 of 1997 concerning Narcotics which contains rehabilitation actions that are ordered to be carried out by narcotics addicts.

This is based on the consideration that most of the prisoners and detainees in drug cases are categorized as users or even victims, which when viewed from the aspect of their health are actually people who are sick, therefore imprisoning the person concerned is not the right step because they have neglected the interests of treatment ${ }^{11}$.

\subsection{Obstacles and Solutions in Law Enforcement of Rehabilitation Sanctions Against Narcotics Users at the Central Java Police}

It is still rare or at least the imposition of rehabilitation sanctions for those who become addicts and victims of narcotics abusers because there are still several obstacles, namely obstacles from the government and obstacles from a legal perspective. The obstacles that come from this government, it is stated that there are 3 (three) obstacles, namely:

- There has not been a special place for addicts and victims of narcotics abusers to rehabilitate.

- The problem of rehabilitation costs for convicts of narcotics abuse cases.

- There is no rehabilitation center appointed by the government. ${ }^{12}$

From the explanation above, it can be explained that the obstacle regarding the absence of a special place for addicts and victims of narcotics abusers, in terms of handling this rehabilitation is still borrowing medical places such as hospitals. The hospital is not a special place to deal with rehabilitation problems for drug users, but only provides assistance. Regarding the problem of rehabilitation costs for convicts of narcotics abuse cases, the judge views that the state's budget to finance rehabilitation treatment for convicts is still very minimal.

For the problem of the absence of a rehabilitation center appointed by the government, this raises the problem of where will the convicts of narcotics abuse cases be placed. Because there is no clear appointment of a rehabilitation center by the government, it can cause confusion for judges in deciding narcotics cases,

\footnotetext{
${ }^{11}$ See item 1 SEMA No. 07 of 2009

${ }^{12}$ Interview with Ulung Pribadi, SH, Member of Sub-Directorate of Drugs 3 of the Central Java Police, on June 29, 2021 at 10.00 WIB.
} 
confused about where the convict will be placed if it is decided to carry out rehabilitation. Because the judge did not know for sure which rehabilitation centers could be appointed to treat the convicts. In addition, regarding legal obstacles, namely:

- There was a difference in the statements between the defendant, the witness and the results of the criminalistic laboratory.

- An execution problem occurred. With the difference in information between the defendant, the witness and the results of the criminalistic laboratory, it can also make the judge think more about imposing a rehabilitation sanction for the defendant. Sometimes the judge will find a situation where a defendant who claims to be a victim of a narcotics abuser is also justified by testimony from a witness, but based on the results of a criminalistic laboratory test, states that the defendant both urine and blood are negative for narcotics.

In terms of execution, the judge must also think about whether the defendant will be able to carry out the judge's decision as well as possible. Seeing the high cost of rehabilitation and with a very minimal government budget, this led to a decision that the defendant was obliged to undergo rehabilitation at his own expense, even though there was a possibility that the defendant was from a group with a low social status so that he could not carry out the sanctions. Thus, if the judge's decision in the end cannot be implemented, it will lead to unclear legal certainty. ${ }^{13}$

The solutions to the existing problems are:

- Provision of special places for addicts and victims of narcotics abusers to rehabilitate.

- Provision of subsidies to reduce rehabilitation costs for convicts of narcotics abuse cases.

- Make it easier for narcotics users to rehabilitate in rehabilitation homes.

- Increasing resources for law enforcement officers in the process of resolving drug abuse.

\section{Closing}

The conclusion in this study is that looking at the criminal provisions of Article 127 paragraphs (2) and (3), it can be concluded that addicts and victims of narcotics abuse can be rehabilitated both medical rehabilitation and social rehabilitation and are no longer sentenced to prison or imprisonment. The obstacles that come from the government, it is stated that there are 5 (five) obstacles, namely: a) There has not been a special place for addicts and victims of narcotics abusers to rehabilitate, b) The problem of rehabilitation costs for convicts of abuse cases narcotics, c) There is no rehabilitation center appointed by the Government, d) There is a difference in information between the defendant, witnesses and the results of the criminalistic laboratory, e) There is a problem with execution. The solutions to the existing problems are:

\footnotetext{
${ }^{13}$ Interview with Slamet, SH, MH, Head of Narcotics Division for General Crimes at the Central Java High Court, on 30 June 2021 at 10.00 WIB.
} 
Suggestions for this research is that regulations regarding rehabilitation of narcotics abusers in the future should be more firm, one of which is expected to be formulated a Government Regulation that regulates abusers who must carry out rehabilitation and which abusers can be sentenced, then to law enforcement officials, in this case investigators, prosecutors as well as judges must be able to firmly formulate the status of a narcotics criminal who can be rehabilitated, whether an abuser, addict or victim of narcotics abuse, this is intended so that later sanctions can be imposed as fair as possible and aspects of legal protection for victims of narcotics abusers can be realized.

\section{References}

\section{Journal}

[1] Adhe I smail A, Constitutionalism Concept in Implementation of Indonesian State Administration. Jurnal Daulat Hukum Volume 4 Issue 2, June 2021 ISSN: 2614560X.

[2] Ardito, Y P, Umar Ma'ruf and Aryani Witasari. Implementation of Criminal Action Prosecution Online in Realizing Principle of Fast Prosecution, Simple \& Low Cost, Jurnal Daulat Hukum, Volume 4 Issue 2, June 2021 ISSN: 2614-560X.

[3] Feri, S W, and Arpangi. Settlement Policy of Criminal Actions which Performed by Children through Penal Mediation. Jurnal Daulat Hukum Volume 4 Issue 2, June 2021 ISSN: 2614-560X.

[4] Indah Lestari, Sri Endah Wahyuningsih, Penegakan Hukum Pidana Terhadap Pengguna Narkoba di Polda Jateng, Jurnal Hukum Khaira Ummah, Vol.2 No.3, September 2017.

[5] Nurfita A T, Sri Endah Wahyuningsih dan Arpangi. The Police Role in Investigating the Crime of Child Murder as a Result of Infidelity Relationships. Law Development Journal ISSN : 2747-2604 Volume 3 Issue 1, March 2021.

[6] Sri Endah Wahyuningsih, 2014, Urgensi Pembaharuan Hukum Pidana Materiel Indonesia Berdasarkan Nilai-Nilai Ketuhanan Yang Maha Esa, Jurnal Pembaharuan Hukum Volume 1 No.1, Januari-April 2014.

[7] Yusril I A, Bambang Tri Bawono and Ira Alia Maerani, Criminal Investigation of Motorcycle Stealing Goods. Law Development Journal ISSN : 2747-2604 Volume 3 Issue 1, March 2021.

\section{Book}

[1] Dadang Hawari, Psikiater, 2006, Penyalahgunaan \& Ketergantungan NAZA (Narkotika, Alkohol, \& Zat Adiktif), Jakarta : Gaya Baru.

[2] Soerjono Soekanto, 2010, Pengantar Penelitian Hukum, Universitas Indonesia Press, Jakarta. 